36. Bykova E.A., Gashev S.N., Levykh A.Yu. Natural and historical aspects of the origin and functioning of urban mammals in western Siberia, Russia and Uzbekistan // Acta Biologica University Daugavpils. 2015. 15 (1). C. 4-64.

37. Левых А.Ю. Биомониторинг окружающей среды г. Ишима как индикатор качества жизни // XXVI Ершовские чтения: сборник научных статей с междунар. участием. Ишим: ИПИ им. П.П. Ершова, 2016. C. 19-26.
38. Левых А.Ю. Морфогенетическая структура популяций разных видов мелких млекопитающих на юге Тюменской области и биотопические особенности её формирования // Экологический мониторинг и биоразнообразие. 2007. Т. 2, № 1. С. 1-142.

39. Гашев С.Н., Быкова Е.А., Левых А.Ю. Устойчивость сообществ мелких млекопитающих урбаценозов в различных природных зонах // Известия Самарского научного центра РАН. 2015. Т. 17, № 6. C. $14-18$.

\title{
SMALL MAMMALS IN THE BIOMONITORING SYSTEM OF PROTECTED AREAS (ON THE EXAMPLE OF THE ISHIM DISTRICT OF THE TYUMEN REGION)
}

(C) 2018

\author{
Levykh Alyona Yuryevna, candidate of biological sciences, associate professor, \\ head of Biology, Geography and Teaching Methods Department \\ P.P. Ershov Ishim Pedagogical Institute (branch) of Tyumen State University \\ (Ishim, Tyumen Region, Russian Federation)
}

\begin{abstract}
The article presents the results of the field studies of small mammals carried out from 1997 till 2017 on three specially protected natural areas of the Ishim District of the Tyumen Region (on the example of subzone of the northern forest-steppe). The method of synecology helped to analyze both the species and structural diversity and integral indices of the state of communities. The method of epigenetics aimed to show the stability of development in the populations of dominant species (on the example of Myodes rutilus and Sorex araneus). The article shows that the level of species diversity and stability of small mammalian communities is directly proportional to the area of specially protected natural areas and reversely proportional to the level of anthropogenic load on the habitat. High anthropogenic load is the reason of neutrals and anthropophiles disappearing from communities of small mammals. The index of dominance of Apodemus agrarius increases as well as the exoanthropic species. The author establishes that the information structure of all studied communities is that of poorly disturbed habitats of the forest-steppe zone of Western Siberia. The information structure of the small mammals community of the most protected areas (1108 hectares), experiencing minimal anthropogenic impact is consistently reproduced in the number of years. The analysis of small mammals' community showed a low resource potential of a forest park with an area of 14,5 hectares, located in the center of the city. At the same time the integral indices of the fluctuating asymmetry of the nonmetric features of the skull in the investigated populations of M. rutilus and S. araneus indicate the stability of epigenetic processes and the good state of the land and air environment.

Keywords: small mammals; rodents; common shrews; indices of diversity; sustainability; domination; alignment; ecological groups; nonmetric signs of skull; fluctuating asymmetry; stability of development; synecology; epigenetics; biomonitoring; specially protected natural areas.
\end{abstract}

УДК 582.711.713 - 146:631.529 (470.1/.2)

Статья поступила в редакцию 30.04.2018

\section{ИЗУЧЕНИЕ ОСОБЕННОСТЕЙ РЕПРОДУКТИВНЫХ СТРУКТУР АMYGDALUS NANA L. ПРИ ИНТРОДУКЦИИ НА СЕВЕРЕ}

(C) 2018 Мифтахова Светлана Алексеевна, кандидат биологических наук,
научный сотрудник отдела Ботанический сад

Скроцкая Ольга Валерьевна, кандидат биологических наук, старший научный сотрудник, временно исполняющий обязанности заведующего отделом Ботанический сад

Институт биологии Коми научного цеентра УрО РАН (2. Сыктывкар, Российская Федерация)

Аннотащуия. В результате изучения строения цветков растений Amygdalus nana при интродукции в средней подзоне тайги Республики Коми показано его соответствие видовым признакам растения. Вместе с тем отмечены тератологические изменения, которые выражаются в аномальном развитии стерильных и фертильных структур цветков (махровость - увеличивается число лепестков, их края приобретают волнистость, происходит преобразование тычинок в лепестки; недоразвитие пестика и др.). Прослежен жизненный цикл цветков A. nana в условиях Севера, определена продолжительность фаз их развития (от фазы плотного зеленого бутона до фазы отцветания). Показаны особенности процесса плодоношения особей A. nana, где отмечена дегенерация оплодотворенных семязачатков, происходящая из-за возможного нарушения разных этапов эмбриогенеза. При этом значительное число аномалий в фертильных частях цветка, вероятно, является причиной, приводящей к формированию малого количества плодов на растениях. Проведенный анализ строения цветков A. nana в условиях средней подзоны тайги Республики Коми дает дополнительные сведения о внутривидовых изменениях репродуктивных структур данного растения. Полученные результаты могут служить дополнительной информацией для установления антэкологических различий внутри таксона. 
Ключевые слова: Amygdalus nana; репродуктивная сфера; строение цветка; жизненный цикл цветка; фертильные и стерильные структуры цветка; тератологические изменения; интродукция; редкое древесное растение; средняя подзона тайги; Республика Коми; холодный климат; Ботанический сад.

Во флоре Республики Коми относительно немного красивоцветущих древесных растений, в связи с чем особую роль в обогащении культурной флоры приобретает интродукция полезных растений, которая является одним из ведущих направлений деятельности ботанических садов, сохраняющих и изучающих достаточно большие и разнообразные коллекции живых растений.

Ботанический сад Института биологии Коми НЦ УрО РАН - один из самых северных, расположен в 8 км от г. Сыктывкара $\left(61,6^{\circ}\right.$ с.ш., 50,8 ${ }^{\circ}$ в.д.). Наибольшее число дней в году здесь приходится на зимний период. За вегетационный период (150 дней), начинающийся в третьей декаде апреля при среднесуточной температуре воздуха выше $+5^{\circ} \mathrm{C}$ сумма суточных температур достигает $1800^{\circ} \mathrm{C}$, за период активной вегетации (90-110 дней) со среднесуточными температурами $+10^{\circ} \mathrm{C}$ и выше $-1450^{\circ} \mathrm{C}$. Район интродукции характеризуется достаточным увлажнением: среднегодовая сумма осадков - 500-600 мм (400-450 мм выпадает в теплый период года) [1, с. 96; 2, с. 11-94]. Местоположение Ботанического сада существенно влияет на состав коллекций живых растений, в том числе дендроколлекцию, которая к настоящему времени насчитывает около 600 видов, образцов, форм и сортов. В дендрарии изучаются представители 21 рода семейства Rosaceae, являющиеся ценными в хозяйственном отношении видами; в частности многие из них представляют интерес как красивоцветущие и декоративно-лиственные растения для ландшафтного дизайна городов Республики Коми [3, с. 203-207; 4, с. 10-12; 5, с. 203-207]. Одним из перспективных декоративных растений этого семейства является Amygdalus nana L. - миндаль низкий, относящийся к роду Prunus. Вид внесен во многие региональные Красные книги [6, с. 108-110 и др.].

Это низкий кустарник с торчащими побегами и многочисленными укороченными веточками с линейно-ланцетными заостренными пильчатыми листьями. На укороченных побегах листья собраны в пучки. Войлочно-мохнатые округло-яйцевидные сухие плоды-костянки соломенно-желтого цвета. Каждый плод имеет одно семя. Из ядрышек готовят второсортное миндальное масло или горьковатую лечебную минеральную воду [7, с. 175-187; 8, с. 87]. Исследован биохимический состав растений A. nana в природе и культуре [9, с. 56-57]. В качестве декоративного раноцветущего кустарника может широко использоваться в озеленении в средней полосе европейской части России $[10$, с. $724 ; 11$, с. 334-337; 12, с. $108-111 ; 13$, с. 202-211]. Климатические условия средней подзоны тайги Республики Коми для A. nana довольно суровые. Однако вид достаточно зимостойкий, что было выявлено ранее при испытании в Ботаническом саду образца A. nana, который по неизвестным причинам в настоящее время отсутствует. Установлено, что растение в культуре на Севере нетребовательно и отличается красивым цветением. Поэтому рекомендуется продолжить его изучение, привлекая образцы разного географического происхождения.

Изучение особенностей репродуктивных органов культурных растений, в частности их устойчивость к неблагоприятным факторам места интродукции, является необходимым этапом для установления возможности растений возобновляться семенным путем и для успешной их адаптации в новых условиях произрастания. Известны работы, посвященные изучению процессов репродукции некоторых представителей подсемейства Prunoideae, в том числе и A. nana $[14$, с. $957-963$; 15 , с. $9-12 ; 16$, с. $21-23 ; 17$, с. $269-$ $272 ; 18$, с. 26-36; 19, с. 325-330] в разных климатических условиях. Также актуальны исследования, связанные с изучением дикорастущих образцов данного вида в качестве доноров с ценными в селекционном плане признаками, сохраняемыми для создания генетических коллекций косточковых растений для дальнейшей аналитической селекции и отбора генотипов с целью получения сорта [20, с. 14-25]. В связи с чем представляет интерес исследование генеративной сферы растений $A$. папа, культивируемых в северном регионе, где могут проявиться какие-либо изменения в строении цветков данного вида из-за влияния экологических условий района интродукции. Поэтому целью данной работы являлось изучение особенностей репродуктивных структур А. папа при интродукции в средней подзоне тайги Республики Коми.

\section{Объект и методика исследований}

Объектом исследований был образец A. nana, полученный саженцами из Главного ботанического сада им. Н.В. Цицина РАН (Москва) в 1995 году. Наблюдения за цветением особей и изучение строения цветков проводились в течение двух вегетационных периодов (2014, 2015 гг.). При описании генеративной сферы руководствовались Атласами по описательной морфологии $[21 ; 22]$. Использовали микроскоп MC-2 ZOOM с камерой DCM130 (1,3 Mpixels).

\section{Результаты и их обсуждение}

В условиях интродукции на Севере строение репродуктивных органов A. nana соответствует видовым особенностям данного таксона. Цветки полные, обоеполые, симметричные (актиноморфные), с короткой цветоножкой, циклические. Их части расположены кругами: чашелистики, лепестки, 2 ряда тычинок, плодолистик (рис. 1). Покров цветка расчленен на чашечку и венчик. Чашечка пятичленная, сростнолистная, зеленого цвета. Сросшиеся основания чашечки образуют воронковидный гипантий. Края чашелистиков мелкопильчатые.

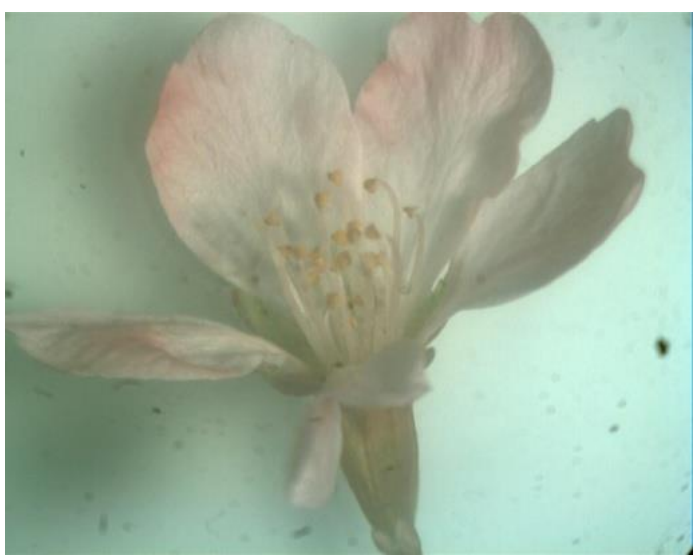

Рисунок 1 - Цветок $A$. папа 
Венчик состоит из 5 свободных обратнояйцевидных слабовыемчатых гладких розовых лепестков.

Строение фертильных частей цветка следующее. Андроцей представлен расположенными в два условных круга (наружный и внутренний) свободными околопестичными до начала цветения загнутыми внутрь цветка тычинками в количестве от 21 до 29 шт., которые прикрепляются к краю гипантия с внутренней стороны (рис. 2). Расхождение тычинок происходит во время цветения. Относительно друг друга они неравные. Тычиночная нить по характеру поверхности голая, по форме - шиловидная. На вершине тычиночной нити неподвижно прикреплен яйцевидный (сердцевидный) пыльник с двумя теками половинками пыльника (рис. 3). Вскрывается пыльник по бокам - продольно.

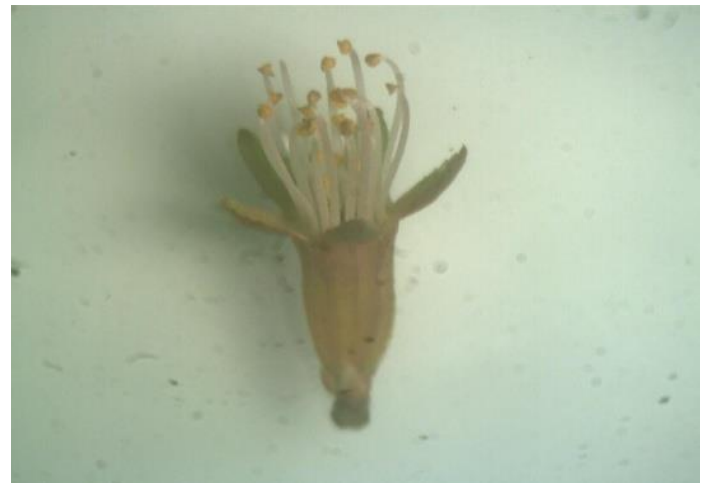

Рисунок 2 - Фертильные части цветка

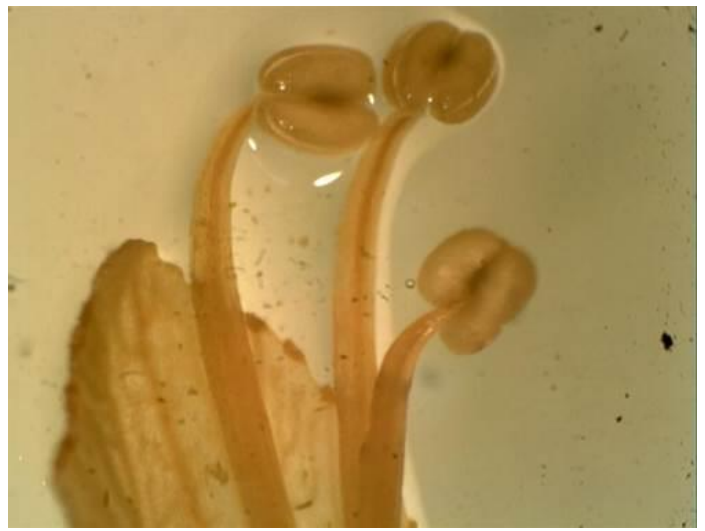

Рисунок 3 - Тычинки

Пестик с верхней округлой двухгнездной завязью, которая к моменту цветения становится одногнездной. Поверхность завязи и столбик опушены, но во время цветения последний вытягивается и становится опушенным наполовину (рис. 4). Л.Ф. Яндовка и И.И. Шамров $[18$, с. $26-36]$ отмечают, что гинецей образован двумя неодинаковыми по величине плодолистиками с разной степенью развития и репродуктивной способностью: большого - фертильного и маленького - стерильного; в стерильном плодолистике завязь не образует гнездо и не полностью срастается с завязью фертильного плодолистика; рыльце сложное и перед оплодотворением состоит из трех лопастей, две из которых образованы фертильным плодолистиком.

В условиях интродукции на Севере наряду с нормально сформированными цветками отмечены и аномальные. Это связано с недоразвитием и увеличением стерильных и фертильных частей цветка. Наблюдались: петализация - преобразование тычин- ки в лепесток (рис. 5); цветки с шестью и семью лепестками (рис. 6, 7), с вырезами по краям, со сросшимися тычинками (рис. 8), трехгнездной завязью, значительное число цветков на особи с недоразвитым пестиком (рис. 9).

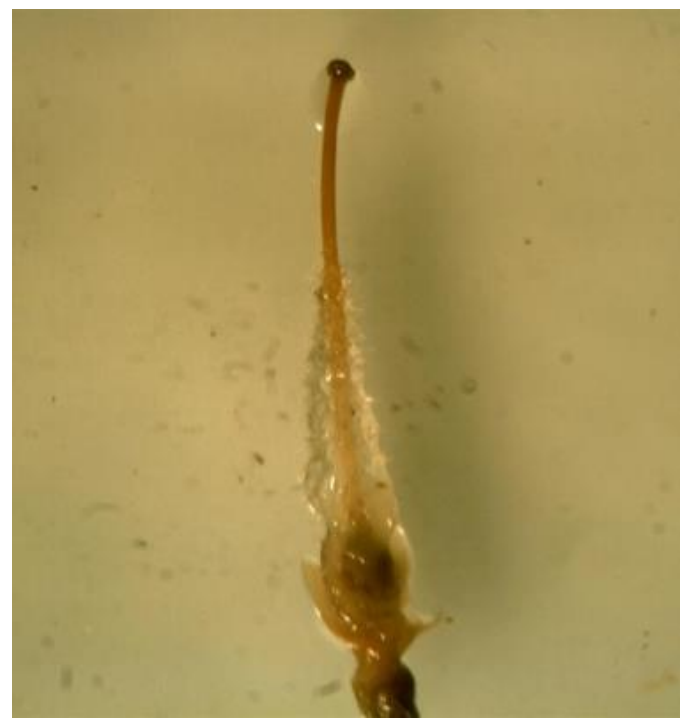

Рисунок 4 - Пестик

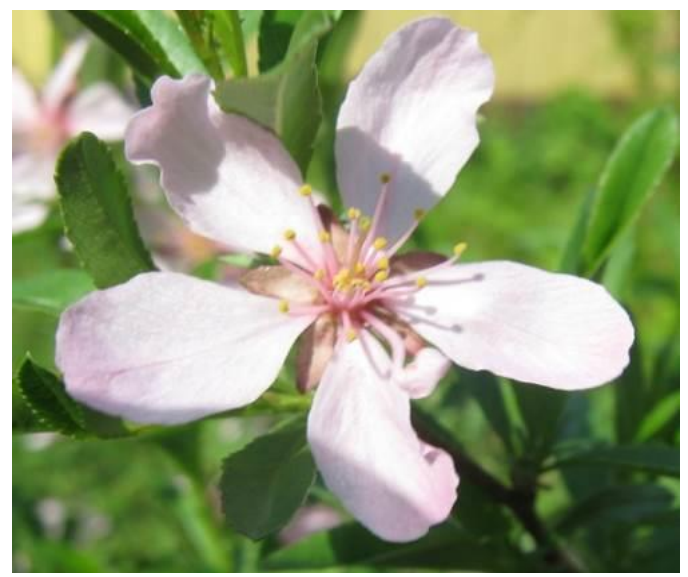

Рисунок 5 - Петализация тычинки

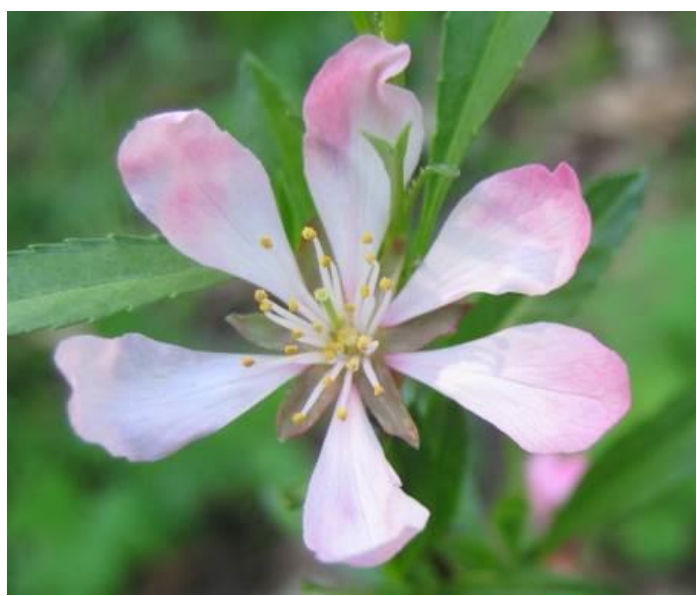

Рисунок 6 - Цветок с шестью лепестками

В жизненном цикле цветков растений подсемейства Prunoideae при изучении вопросов антэкологии Л.Ф. Яндовка [23, с. 1576-1580] выделяет пять фаз развития, охватывающих период от плотного бутона до этапа отцветания цветка.

Согласно данной классификации, I фаза - «плотный зеленый бутон» в условиях средней подзоны тайги Республики Коми оканчивается в конце первой 
декады мая, являясь самой продолжительной. В этот период все части цветка находятся под зелеными плотно сомкнутыми чашелистиками, при этом последние имеют большую длину, чем лепестки. Тычинки плотно прижаты к пестику.

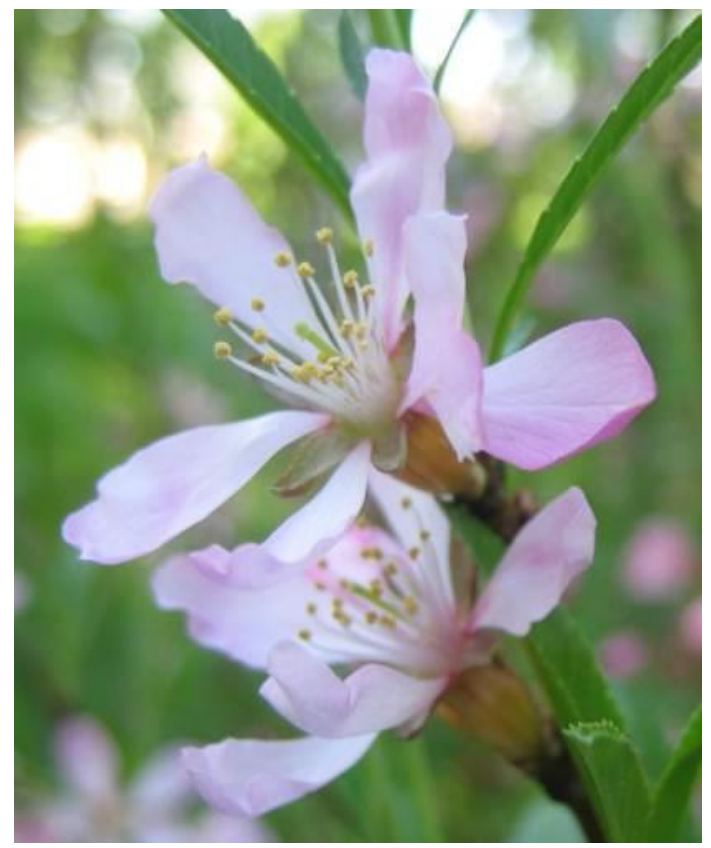

Рисунок 7 - Цветок с семью лепестками

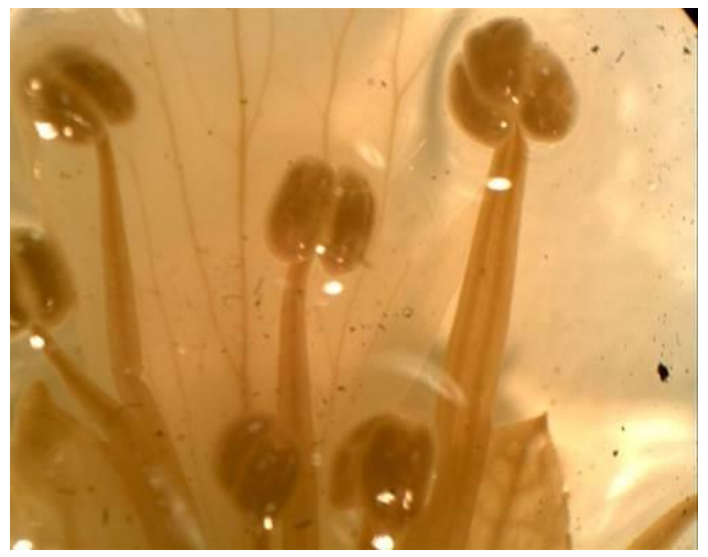

Рисунок 8 - Сдвоенная тычинка

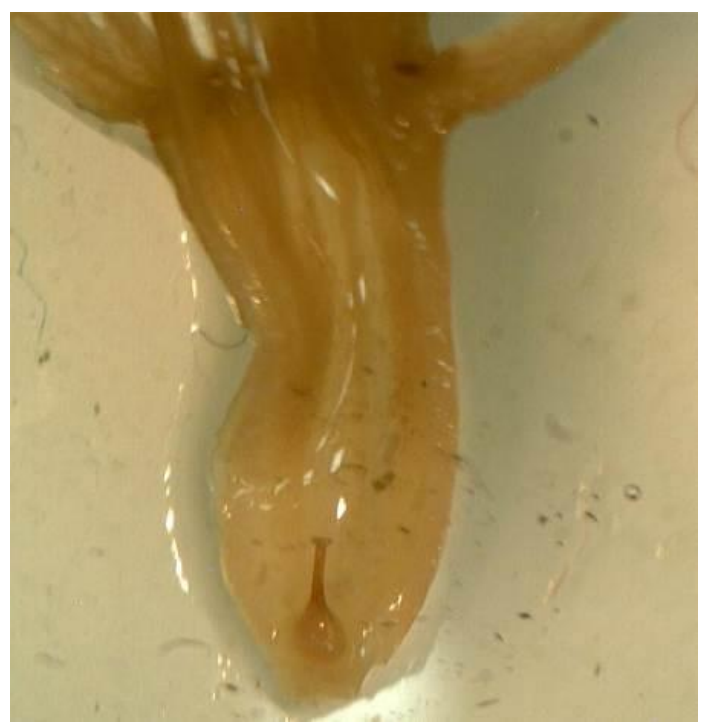

Рисунок 9 - Недоразвитый пестик

II фаза - «белый бутон» (для A. nana это фаза «розовый бутон») делится на две стадии: ІІа - «розо- вый плотный бутон» (вторая декада мая) и ІІб - «розовый рыхлый бутон» (19-21 мая). На этапе развития «розовый плотный бутон», несмотря на довольно близкое расположение всех структур цветка, происходит рост столбика и тычиночных нитей, удлинение лепестков, длина которых в 1,5 раза превышает таковую чашелистиков (рис. 10).

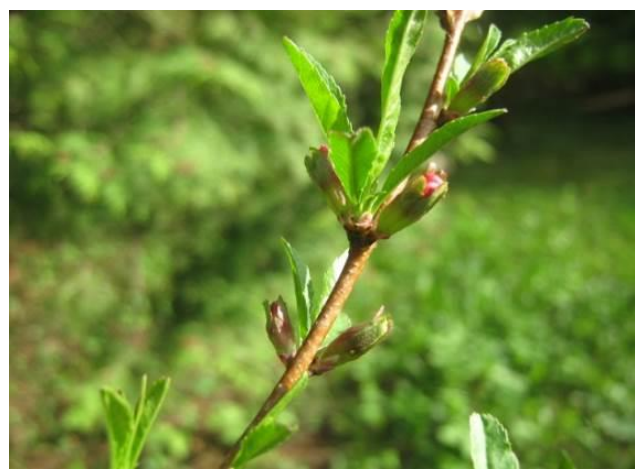

Рисунок 10 - Бутонизация $A$. папа

На стадии «розовый рыхлый бутон» заметно довольно быстрое увеличение всех структур цветка: лепестки в два раза превышают длину чашелистиков (рис. 11), тычиночные нити, распрямляясь, выносят тычинки наружного круга почти к рыльцу пестика (рис. 12, 13).

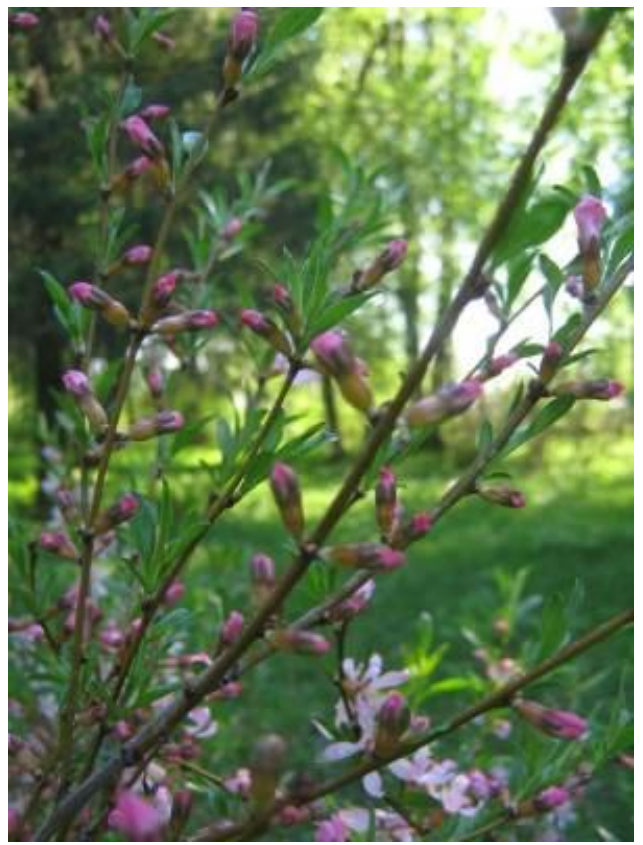

Рисунок 11 - Бутонизация, стадия «розовый рыхлый бутон»

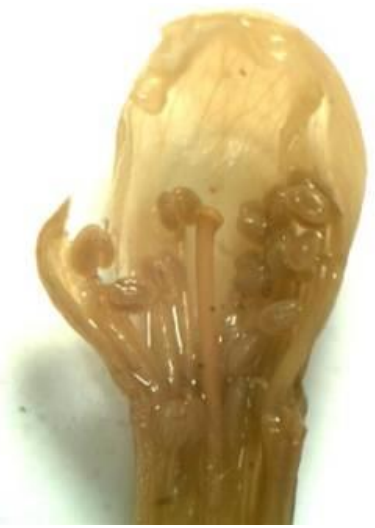

Рисунок 12 - Репродуктивные структуры цветка 


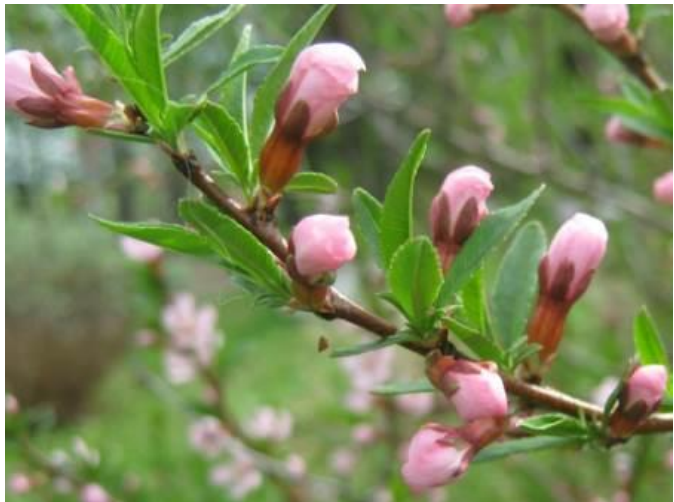

Рисунок 13 - Стадии: рыхлый и плотный бутон

С началом распускания цветка наступает III фаза (начало третьей декады мая). Лепестки и чашелистики начинают отходить от пестика и тычинок. Рыльце и наружный круг тычинок находятся почти на одном уровне (рис. 14).

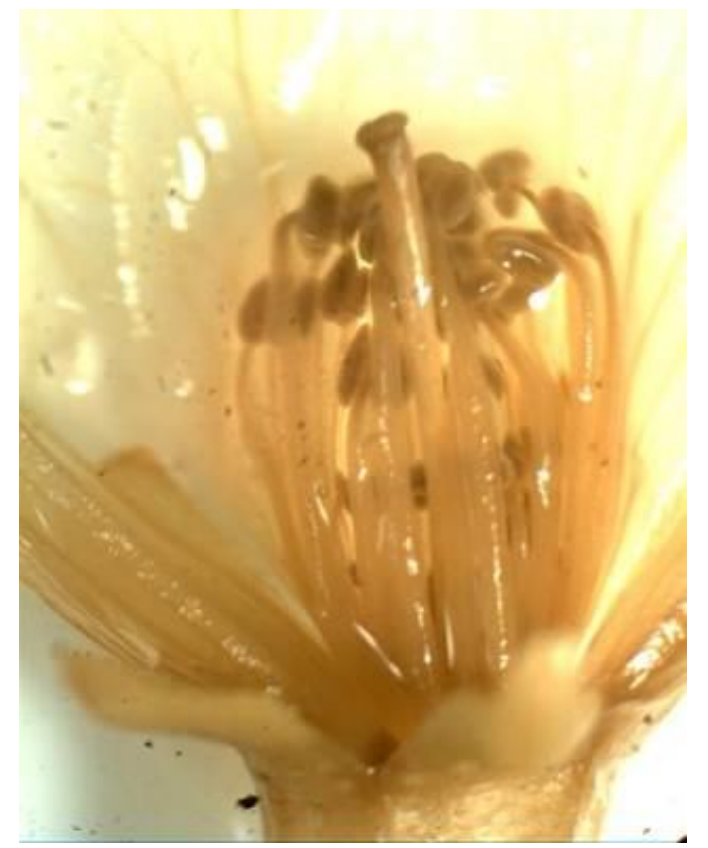

Рисунок 14 - III фаза - начало распускания цветка

При полном распускании цветка (IV фаза) лепестки отгибаются и занимают горизонтальное положение (рис. 15), большее число тычинок наружного круга уже располагаются на высоте пестика (рис. 16). Цветение одного цветка в условиях интродукции составляет 3-4 дня.

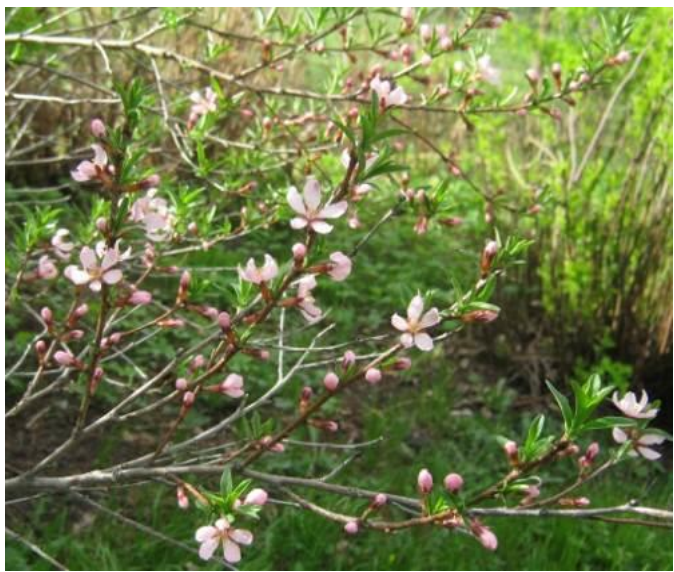

Рисунок 15 - IV фаза - цветение: стадия полного распускания цветка

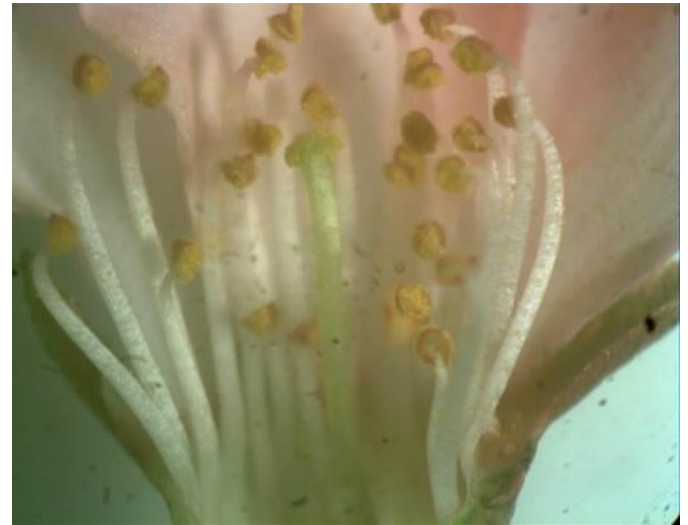

Рисунок 16 - IV фаза - цветение: репродуктивные структуры (на рыльце пестика - пыльца)

Распускание первых цветков наблюдается 2226 мая в зависимости от года исследований, у особей A. nana, выращиваемых на освещенном месте, начало цветения наступает на 4-8 дней раньше. Поскольку опыление растений $A$. nana осуществляется насекомыми, распускание цветков происходит в светлое время суток. Одновременно на растении можно увидеть несколько стадий жизненного цикла цветка (от плотного зеленого бутона до отцветания).

Отцветание (V фаза) характеризуется опадением лепестков, подсыханием тычинок и пестика, что в разные годы приходится на конец мая - начало июня (рис. 17).

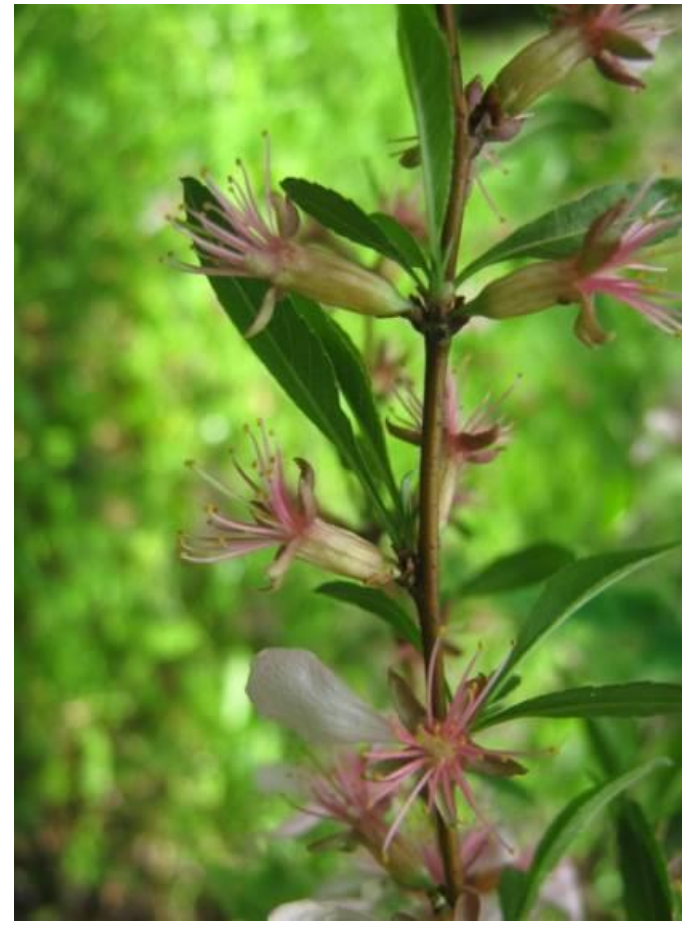

Рисунок 17 - V фаза - отцветание

Плод A. nana - яйцевидная, опушенная костянка с хорошо различимым брюшным швом (рис. 18). Плоды одиночные, в начале плодоношения - зеленые, по мере созревания становятся песочного цвета, с конца июля твердеют. Плодоношение охватывает период с начала первой - второй декад июня до второй декады сентября в зависимости от погодных условий года исследований, сроки начала и завершения данной фазы развития изменяются в пределах 7 дней. Плоды остаются на растении в течение всего зимнего периода, их растрескивание происходит только следую- 
щей весной. Число плодов в период изучения было незначительным. К тому же не все из них содержали полноценные семена, некоторые были неспецифических (меньших) для вида размеров. Вероятно, невыполненность семян связана с прохладными условиями в период созревания, а также, по мнению Л.Ф. Яндовка и В.М. Тарбаевой [24, с. 51-58], нарушения процессов эмбриогенеза (как на начальных, так и на поздних этапах) приводят к недоразвитию семязачатков. Исследователи отмечают возможность сброса в определенные периоды онтогенеза значительного числа завязей, что является эволюционным приспособительным эффектом, в результате которого происходит самосохранение растения.

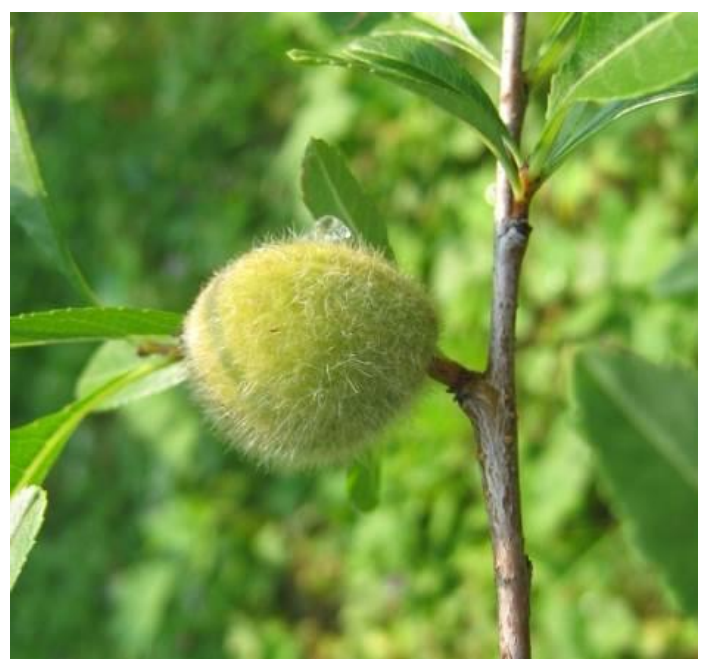

Рисунок 18 - Плод A. папа - костянка

\section{Выводы}

Таким образом, изучение генеративной сферы растений A. nana при интродукции в средней подзоне тайги Республики Коми показало, что строение цветков соответствует видовым признакам растения. Вместе с тем выявлены некоторые отклонения, выражающиеся в нарушении развития стерильных или фертильных структур: махровость - увеличение числа лепестков, изменение целостности их очертаний (волнистый край), петализация, недоразвитие пестика. Показаны особенности процесса плодоношения особей A. nana, обращено внимание на явление дегенерации оплодотворенных семязачатков из-за возможного нарушения разных этапов эмбриогенеза. При этом значительное число аномалий в фертильных частях цветка, возможно, приводит к формированию малого количества плодов на растениях.

Проведенный анализ строения цветков A. nana дополняет сведения о внутривидовых изменениях репродуктивных структур данного растения, связанных с выращиванием его в условиях Севера, отличных от его природного ареала; полученные результаты могут служить дополнительной информацией для установления антэкологических различий внутри таксона.

\section{Список литературы:}

1. Ботанический сад Института биологии Коми НЦ УрО РАН / отв. ред. А.И. Таскаев. М.: Издательско-продюсерский центр «Дизайн. Информация. Картография», 2002. 96 с.

2. Атлас Республики Коми по климату и гидрологии / отв. ред. А.И. Таскаев. М.: Изд-во «Дрофа», $1997.115 \mathrm{c}$.
3. Скроцкая О.В., Мифтахова С.А. Особенности генеративного периода развития видов рода Sorbus L., интродуцированных на Севере (Республика Коми) // Известия Самарского научного центра Российской академии наук. 2015. Т. 17, № 5. С. 203-207.

4. Мифтахова С.А., Скроцкая О.В. Особенности онтогенетического развития и вариабельность содержания флавоноидов у растений Pentaphylloides fruticosa в культуре на Севере (Республика Коми) // Вестник ИБ Коми НЦ УрО РАН. 2015. № 6 (194). C. $10-12$.

5. Скроцкая О.В., Тимушева О.К. Биологические особенности некоторых представителей родов Sorbus, Ribes и Grossularia при интродукции в средней подзоне тайги Республики Коми // Известия Самарского научного центра Российской академии наук, 2016. T. 18, № 2. C. 203-207.

6. Виноградова Е.Н., Митина Л.В., Хархота Л.В. Редкие и исчезающие виды древесно-кустарниковых растений в Донецком ботаническим саду // Сб. науч. тр. Донецкие чтения 2016. Образование, наука и вызовы современности: мат-лы I междунар. науч. конф. / под общ. ред. С.В. Беспаловой. 2016. С. 108-110.

7. Гладкова В.Н. Семейство розовые или розоцветные // Жизнь растений. Т. 5, ч. 2 / под ред. А.Л. Тахтаджяна. М.: Изд-во «Просвещение», 1981. C. $175-187$.

8. Цахуева Ф.П. Биоресурсный потенциал многолетних древесных и кустарниковых растений предгорного Дагестана // Естественные науки. Экология. 2017. № 4 (61). С. 83-90.

9. Киселева Т.И., Кукушкина Т.А., Чиндяева Л.Н. Исследование состава и содержания биологически активных веществ у Amygdalus nana L. в природе и культуре // Вопросы биологической, медицинской и фармацевтической химии. 2014. Т. 12, № 9. С. 56-57.

10. Деревья и кустарники СССР / ред. д.б.н., профессор С.Я. Соколов. М.-Л.: Изд-во АН СССР, 1954. C. 724 .

11. Древесные растения Главного ботанического сада им. Н.В. Цицина РАН: 60 лет интродукции / отв. ред. А.С. Демидов. М.: Изд-во «Наука», 2005. 586 с.

12. Семенютина А.В., Костюков С.М. Оценка результативности семенного размножения кустарников и перспективности их использования для озеленения урболандшафтов засушливого региона // Глобальный научный потенциал. 2015. № 6 (51). С. 108-111.

13. Чепинога И.С. Декоративные формы миндаля низкого (бобовника) в генофонде Крымской ОСС // Селекция, семеноводство и технология плодовоягодных культур и картофеля: сб. науч. тр. Челябинск, 2016. С. 202-211.

14. Яндовка Л.Ф. К вопросу о морфологии цветков Cerasus, Microcerasus, Amygdalus (Rosaceae) // Вестник Тамбовского университета. Серия: Естественные и технические науки. 2011. Т. 16, № 3. C. 957-963.

15. Екимова Н.В., Беловежец Г.П., Вяткина Е.И., Яценко М.Ю. Опыт интродукции представителей рода Amygdalus L. в Сибири // Бюлл. ГБС. 2014. № 4. C. 9-12.

16. Лихенко Н.Н., Боронина А.П. Оценка репродуктивных способностей интродуцентов в лесостепи Приобья // Достижения науки и техники АПК. 2014. № 2. С. 21-23. 
17. Киселева Т.И. Рост и развитие годичного побега Amygdalus nana L. // Проблемы ботаники южной Сибири и Монголии. 2015. № 14. С. 269-272.

18. Яндовка Л.Ф., Шамров И.И. Особенности строения гинецея и семязачатка у представителей родов Cerasus, Microcerasus и Amygdalus (Rosaceae) // Вестник Санкт-Петербургского университета. 2016. Cер. 3, вып. 4. С. 26-36.

19. Чепинога И.С., Гасанова Т.А. Дикорастущие виды миндаля как исходный материал для селекции на адаптивность к абиотическим стрессорам // Труды Кубанского государственного аграрного университета. 2016. № 60. С. 325-330.

20. Еремин Г.В. Сбор, изучение и использование генофонда дикорастущих видов рода Prunus L. // Плодоводство и виноградарство юга России. 2015. № 36 (6). С. 14-25.

21. Федоров А.А., Артюшенко 3.Т. Атлас по описательной морфологии высших растений. Цветок / ред. Г.Н. Антик. Л.: Изд-во «Наука», 1975. 350 с.
22. Артюшенко 3.Т., Федоров А.А. Атлас по описательной морфологии высших растений. Плод. Л.: Наука, 1986. 392 с.

23. Яндовка Л.Ф. Фазы и ритм распускания цветков у Cerasus, Microcerasus, и Amygdalus (Rosaceae) // Вестник Тамбовского университета. Серия: Естественные и технические науки. 2010. Т. 15, № 5. C. $1576-1580$.

24. Яндовка Л.Ф., Тарбаева В.М. Семенная продуктивность у видов Cerasus, Microcerasus и Amygdalus (Rosaceae) // Сибирский вестник сельскохозяйственной науки. 2010. № 8. С. 51-58.

Работа проведена на экспериментальной базе УНУ «Научная коллекция жнивых растений» Ботанического сада Института биологии Коми НЦ УрО РАН, рег. номер 507428. Исследования выполнены в рамках государственного задания по теме «Закономерности процессов репродукции ресурсных растений в культуре на европейском СевероВостоке» № AAAA-A17-117122090004-9.

\title{
AMYGDALUS NANA L. REPRODUCTIVE STRUCTURES FEATURES STUDY WHEN INTRODUCED IN THE NORTH
}

(C) 2018

Miftakhova Svetlana Alekseevna, candidate of biological sciences, researcher of Botanical Garden

Skrotskaya Olga Valerievna, candidate of biological sciences, senior researcher, acting head of Botanical Garden Institute of Biology of Komi Scientific Centre of the Ural Branch of the Russian Academy of Sciences (Syktyvkar, Russian Federation)

Abstract. As a result of Amygdalus nana plant flowers structure study, when introduced in the middle taiga subzone of the Komi Republic, its conformity to the species features of the plant is shown. The authors also note teratological changes, expressed in the abnormal development of sterile or fertile flower structures. The number of petals increases, their edges become wavy; stamens transform into petals, there is pistil underdevelopment, etc. The life cycle of $A$. nana flowers was traced in the conditions of the North, the duration of the phases of their development was determined (Phase I - «dense green bud», II phase of «pink bud», III phase - «beginning of blossoming flower», IV phase - «full blossoming of the flower» and V phase - «fading»). The features of the fruiting process of A. nana are shown, where degeneration of fertilized ovules is noted, which is due to the possible violation of different stages of embryogenesis. In this case, a significant number of anomalies in the fertile parts of the flower, possibly, lead to a small number of fruits on plants. The analysis of the A. nana flower structure in the middle taiga subzone of the Komi Republic gives additional information on the intraspecific changes in the reproductive structures of this plant; the results obtained can serve as additional information for establishing anthocological differences within the taxon.

Keywords: Amygdalus nana; reproductive sphere; flower structure; flower life cycle; fertile and sterile flower structures; teratological changes; introduction; rare woody plant; middle taiga subzone; Komi Republic; cold climate; Botanical Garden.

УДК 581.524.2:635.939.982 (470.321.1-21)

Статья поступила в редакцию 15.05.2018

\section{ИНВАЗИОННЫЕ ВИДЫ СЕМЕЙСТВА АSТЕRАСЕАЕ ВО ФЛОРЕ ГОРОДА КУРСКА}

(C) 2018

\author{
Нагорная Ольга Вячеславовна, кандидат биологических наук, \\ доцент кафедры экологии, садоводства и защиты растений \\ Курская государственная сельскохозяйственная академия имени И.И. Иванова \\ (2. Курск, Российская Федераичия)
}

Аннотация. В статье рассмотрены биологические особенности и количественные характеристики популяций некоторых инвазионных видов семейства Asteraceae во флоре города Курска и их распространение. Город Курск, являясь промышленным и административным центром Курской области, отличается сильной степенью трансформации флоры в результате активного преобразования территории в последние годы, что определяет подходящие условия для внедрения инвазионных видов и их широкого распространения. Во флоре города Курска зарегистрировано 43 инвазионных вида, доля Asteraceae - 21\%. В статье приведены биологические особенности и характеристики популяций таких видов, как дурнишник эльбский (Xanthium albinum) и циклахена дурнишниколистная (Cyclachaena xanthiifolia). Изучены следующие популяционные показатели: число особей, высота и общее проективное покрытие. Выявлено, что популяции Xanthium albinum в различных условиях произрастания проявляют значимые различия по изученным параметрам. В попу- 